\title{
PENGARUH KARAKTERISTIK DAN PERSEPSI INDIVIDU TENTANG PERINGATAN BAHAYA MEROKOK PADA BUNGKUS ROKOK TERHADAP PERUBAHAN SIKAP PEROKOK AKTIF DI LINGKUNGAN XXVII KELURAHAN PEKAN LABUHAN KECAMATAN MEDAN LABUHAN
}

\author{
Eva Nirwana Natalia Hutabarat ${ }^{1}$, R. Kintoko Rochadi ${ }^{2}$, Destanul Aulia ${ }^{3}$ \\ ${ }^{1}$ Peminatan Kesehatan Reproduksi Fakultas Kesehatan Masyarakat Universitas Sumatera Utara \\ Email: nirwana.eva88@gmail.com \\ ${ }^{2,3}$ Fakultas Kesehatan Masyarakat Universitas Sumatera Utara
}

Masuk: 06-03-2018, revisi: 29-05-2019, diterima untuk diterbitkan: 14-08-2019

\begin{abstract}
ABSTRAK
Prevalensi merokok pada orang Indonesia sangat tinggi, terutama pada pria; mereka terdiri dari anak-anak, remaja, dan orang dewasa. Peraturan Pemerintah tentang Peringatan Kesehatan Bergambar (PHW) pada bungkus rokok berakhir untuk melindungi orang dan mengubah sikap mereka terhadap kebiasaan merokok dengan berhenti. Tujuan dari penelitian ini adalah untuk menganalisis pengaruh karakteristik individu dan persepsi tentang peringatan bahaya merokok pada bungkus rokok pada perubahan sikap perokok aktif. Penelitian ini menggunakan metode survei analitik dengan desain cross sectional dilakukan di Lingkungan XXVII, Kelurahan Pekan Labuhan, Kecamatan Labuhan Medan. Populasi adalah 324 orang, dan 248 dari mereka digunakan sebagai sampel. Data dianalisis dengan menggunakan analisis univariat, analisis bivariat dengan uji chi square, dan analisis multivariat dengan analisis regresi logistik ganda. Hasil penelitian menunjukkan bahwa pendidikan, pengetahuan, dan persepsi tentang peringatan bahaya merokok di iklan memiliki pengaruh. tentang perubahan sikap perokok aktif $(p<0,05)$ di Lingkungan XXVII, Kelurahan Pekan Labuhan, sedangkan usia, pekerjaan, dan kebiasaan merokok tidak $(\mathrm{p}>0,05)$. variabel yang memiliki pengaruh paling dominan adalah variabel pendidikan. Perokok aktif yang memiliki pendidikan tinggi, pengetahuan yang baik, dan memiliki persepsi yang baik tentang peringatan akan bahaya merokok pada bungkus rokok dalam iklan memiliki peluang 57\% untuk mengubah sikap mereka yang mengindikasikan bahwa sangat sulit untuk mengubah sikap perokok terhadap merokok karena sudah menjadi kebiasaan. Disarankan agar pemerintah, melalui Dinas Kesehatan, mengevaluasi iklan tentang peringatan bahaya merokok pada bungkus rokok karena banyak perokok tidak mengubah sikap mereka walaupun peringatan itu jelas terlihat dan dapat dimengerti.
\end{abstract}

Kata kunci: Karakteristik; Persepsi Individu; Peringatan Kesehatan Bergambar; Perubahan Sikap; Perokok Aktif

\begin{abstract}
The prevalence of smoking in Indonesian people is very high, especially in males; they consist of children, adolescents, and adults. Government Regulation on Pictorial Health Warning (PHW) on cigarette packs is it ended to protect people and change their attitude toward smoking habit by quitting it. The purpose of this study was to analyze the influence of individual characteristics and perceptions about the warning of smoking hazard on cigarette packs on changing the attitude of active smokers. The research used analytic survey method with cross sectional design. It was conducted at Lingkungan XXVII, Kelurahan Pekan Labuhan, Medan Labuhan Subdistrict. The population was 324 people, and 248 of them were used as the samples. The data were analyzed by using univariate analysis, bivariate analysis with chi square test, and multivariate analysis with multiple logistic regression analysis. The result of the research showed that education, knowledge, and perception on warning for the danger of smoking in advertisements had the influence on the change in active smokers' attitude $(p<0.05)$ at Lingkungan XXVII, Kelurahan Pekan Labuhan, while age, occupation, and smoking habit did not ( $p>0.05)$. the variable which had the most dominant influence was the variable of education. Active smokers who had high education, good knowledge, and had good perception on the warning for the danger of smoking on cigarette packs in the advertisements had the oppurtunity of 57\% to change their attitude which indicated it was very difficult to change smokers' attitude toward smoking since it has become a habit.It is recommended that the government, through the Health Agency, evaluate advertisements about warning for the danger of smoking on cigarette packs since many smokers do not change their attitude although the warning is clearly visible and understandable.
\end{abstract}

Keywords: Characteristic; Individual Perception; Pictorial Health Warning; Change of Attitude; Active Smokers 


\section{PENDAHULUAN}

Data The Tobacco Atlas menyebutkan bahwa penduduk dunia yang mengonsumsi tembakau sebanyak 57\% pada penduduk Asia dan Australia, 14\% pada penduduk Eropa timur dan pecahan Uni Sovyet, 12\% penduduk Amerika, 9\% penduduk Eropa Barat, dan $8 \%$ pada penduduk Timur Tengah serta Afrika. Sementara itu ASEAN merupakan sebuah kawasan dengan 10\% dari seluruh perokok dunia dan $20 \%$ penyebab kematian global akibat tembakau. Persentase perokok pada penduduk di negara ASEAN tersebar di Indonesia (46,16\%), Filipina (16,62\%), Vietnam (14,11\%), Myanmar (8,73\%), Thailand (7,74\%), Malaysia (2,90\%), Kamboja (2,07\%), Laos (1,23\%), Singapura $(0,39 \%)$, dan Brunei $(0,004 \%)$ (Kemenkes RI, 2015).

The Global Adult Tobacco Survey (GATS) Atlas Tahun 2015 menunjukkan jumlah perokok di Indonesia yang berusia 15 tahun ke atas, laki-laki mencapai $67 \%$ dan perempuan 3\%. Menurut data Riset Kesehatan Dasar (Riskesdas) Kementerian Kesehatan (Kemenkes) Tahun 2013, prevalensi perokok us ia 15 tahun ke atas mencapai 36,3\%. Data Global Youth Tobacco Survey 2014 (GYTS 2014) menyebutkan 20,3\% anak sekolah merokok (laki-laki 36\%, perempuan 4,3\%). Walaupun proporsi perokok perempuan lebih rendah dibandingkan laki-laki, namun terjadi peningkatan sebanyak 5 kali lipat dari 1,7\% (1995) menjadi 6,7\% (2013) (Martiany, 2016).

Prevalensi merokok di Indonesia sangat tinggi di berbagai lapisan masyarakat, terutama pada laki-laki mulai dari anak-anak, remaja dan dewasa. Kecenderungan merokok terus meningkat dari tahun ke tahun baik pada laki-laki dan perempuan. Prevalensi perokok 16 kali lebih tinggi pada laki-laki $(65,8 \%)$, dibandingkan perempuan $(4,2 \%)$. Hampir $80 \%$ perokok di Indonesia mulai merokok ketika usianya belum mencapai 19 tahun. Dilihat berdasarkan provinsi, maka proporsi tertinggi perokok setiap hari pada Provinsi Kepulauan Riau (27,2\%), dan terendah di Provinsi Papua (16,2\%). Lima provinsi tertinggi proporsinya adalah Kepulauan Riau, Jawa Barat, Bengkulu, Gorontalo, dan Nusa Tenggara Barat (Kemenkes RI, 2015).

Berdasarkan Riset Kesehatan Dasar (Riskesdas) 2013, jumlah perokok di provinsi Sumatera Utara mencapai $29,7 \%$. Untuk nasional prevalensi perokok laki-laki sebesar 54,1\% sedangkan perokok saat ini di Sumatera Utara menurut Riskesdas 35,7\%. Rata-rata jumlah batang rokok yang dihisap tiap hari oleh lebih dari separuh $(52,3 \%)$ perokok adalah 1-10 batang (Riskesdas, 2013).

Berdasarkan data PHBS Kota Medan, bahwa di kecamatan Medan Labuhan dari 17.235 rumah tangga yang ada, telah dilakukan pemeriksaan PHBS sebesar 54\%. Dari rumah tangga yang diperiksa tersebut, 90,4\% berada pada tatanan sehat utama dan paripurna, ini artinya perilaku hidup bersih dan sehat masyarakat sudah tergolong baik. Namun ada salah satu indikator dari PHBS yang capaiannya tergolong masih sangat rendah yaitu keluarga bebas asap rokok, ini berarti masyarakat yang ada di Kecamatan Medan Labuhan masih banyak yang terpapar asap rokok. Menurut data tersebut, dari 10.776 rumah tangga yang diperiksa, ada 54,7\% berstatus perokok. Perilaku merokok baik di dalam maupun di luar rumah dengan persentase tertinggi yaitu di Kelurahan Pekan Labuhan, dari 1.241 rumah tangga yang diperiksa hanya $34,4 \%$ keluarga yang bebas asap rokok, itu artinya terdapat 65,6\% rumah tangga yang memiliki minimal seorang perokok di dalamnya.

Sesuai dengan Peraturan Pemerintah Nomor 109 Tahun 2012 tentang Pengamanan bahan yang mengandung zat adiktif berupa produk tembakau bagi kesehatan, mewajibkan produsen rokok mencantumkan peringatan tentang bahaya rokok, Peringatan itu mesti dicantumkan di bagian atas bungkus seluas masing-masing 40 persen dari bungkus, baik di bagian depan maupun belakang. Peringatan yang sama juga harus dicantumkan dalam iklan produk tembakau. Selain peringatan berupa tulisan produsen rokok juga dianjurkan untuk mulai menggunakan peringatan dalam bentuk gambar seperti yang telah dilakukan oleh produsen rokok di beberapa negara lain. Peraturan Pemerintah tersebut diperkuat dengan terbitnya Peraturan Menteri Kesehatan No. 28 Tahun 2013 tentang "Pencantuman Peringatan Kesehatan dan Informasi Kesehatan pada Kemasan Produk Tembakau Berbentuk Gambar dan Tulisan". Dengan adanya informasi kesehatan berupa gambar tersebut, diharapkan dapat meningkatkan 
pengetahuan perokok tentang bahaya yang ditimbulkan akibat dari merokok. Peraturan Pemerintah mengenai penggunaan Peringatan Kesehatan Bergambar (Pictorial Health Warning/ PHW) pada kemasan rokok merupakan upaya yang dilakukan pemerintah untuk melindungi warga negaranya.

Upaya pemerintah tersebut sampai saat ini belum menunjukkan hasil yang menggembirakan, karena perokok makin mudah dijumpai di tempat-tempat umum karena tidak adanya sanksi yang tegas bagi perokok. Iklan antirokok yang gencar dilakukan di media bahkan di bungkus rokok itu sendiri juga tidak membuat masyarakat takut untuk merokok. Contohnya iklan yang dibuat Kemenkes tentang pengakuan korban kanker faring sebagai sesuatu anomali tidak merubah perilaku perokok pasif. Sebaliknya, iklan yang ditampilkan produsen rokok di media massa menunjukkan gaya hidup modern, iklan rokok menampilkan image yang bagus seperti macho, kuat, jantan dan gagah perkasa. Selain itu, iklan rokok juga dibalut kalimat-kalimat motivasi dan menarik bagi kalangan muda, karena produsen rokok ingin menjerat kalangan muda sehingga akan merokok sampai tua. Iklan rokok tersebut yang selalu menampilkan sosok laki-laki muda yang gagah, ganteng, berotot, tinggi, disertai dengan petualanganpetualangan mereka yang hebat dan luar biasa kontras sekali dengan akibat buruk yang di timbulkan rokok itu sendiri. Gambar peringatan bahaya rokok pada bungkus rokok diharapkan membuat perokok jera dan terjadi perubahan sikap untuk memutuskan berhenti merokok (Aula, 2014).

Ajzen (1991) yang mengatakan bahwa sikap mempengaruhi perilaku lewat suatu proses pengambilan keputusan yang teliti dan beralasan dan dampaknya terbatas hanya pada tiga hal; Pertama, perilaku tidak banyak ditentukan oleh sikap umum tapi oleh sikap yang spesifik terhadap sesuatu. Kedua, perilaku dipengaruhi tidak hanya oleh sikap tapi juga oleh norma-norma objektif (subjective norms) yaitu pengetahuan dan kesadaran atau keyakinan kita mengenai apa yang orang lain inginkan agar diperbuat. Ketiga, sikap terhadap suatu perilaku bersama norma-norma subjektif membentuk suatu intensi atau niat berperilaku tertentu.

Salah satu lingkungan di Kelurahan Pekan Labuhan yang memiliki perokok aktif adalah lingkungan XXVII. Jumlah perokok sebanyak 324 dari 536 jumlah penduduk dewasa yang bertempat tinggal di lingkungan tersebut. Survei pendahuluan yang peneliti lakukan dengan mewawancarai 15 orang perokok pasif tentang sikap mereka terhadap gambar peringatan pada bungkus rokok (picture health warning) yang berisi gambar kanker mulut, kanker tenggorokan, kanker paru, yang menunjukkan bahwa sebanyak 8 orang $(53,3 \%)$ mengatakan biasa-biasa saja, tidak merokok juga akan mati, 4 orang (26,7\%) mengatakan takut tetapi tidak dapat menghentikan kebiasaan merokok tersebut yang sudah dilakukan sejak remaja, 3 orang $(20,0 \%)$ mengatakan merokok sudah seperti makan nasi sehingga tidak bisa ditinggalkan kalau masalah peringatan bahaya merokok itu tidak semua kena menurut mereka. Buktinya ada orang yang merokok dari muda tetapi sampai tua (berumur lebih dari 70 tahun), tetapi ada orang yang tidak merokok tetapi mati muda.

Tujuan penelitian ini yaitu untuk menganalisis pengaruh karakteristik dan persepsi individu tentang peringatan bahaya merokok pada bungkus rokok terhadap perubahan sikap perokok aktif di Lingkungan XXVII Kelurahan Pekan Labuhan Kecamatan Medan Labuhan Tahun 2017.

\section{METODE PENELITIAN}

Jenis penelitian ini survei analitik dengan desain potong lintang (cross sectional). Penelitian ini dilaksanakan di Lingkungan XXVII Kelurahan Pekan Labuhan Kecamatan Medan Labuhan. Populasi penelitian ini adalah seluruh perokok aktif sebanyak 324 orang. Sampel diperoleh sebanyak 248 orang. Data yang digunakan adalah data primer dan sekunder. Data dianalisis menggunakan analisis univariat, analisis bivariat dengan uji chi-square, dan analisis multivariat dengan menggunakan uji regresi logistik berganda pada taraf kepercayaan $95 \%(\alpha=0,05)$. 


\section{HASIL PENELITIAN}

Karakteristik responden yaitu sebagian besar responden dewasa sebanyak 244 orang $(98,4 \%)$, berpendidikan tinggi (D-3 dan S1) sebanyak 133 orang (53,6\%), bekerja sebagai wiraswasta sebanyak 66 orang $(26,6 \%)$. Berdasarkan hasil penelitian responden berpengetahuan baik sebanyak 137 orang $(55,2 \%)$. Sebagian kecil responden berpengetahuan kurang sebanyak 111 orang $(44,8 \%)$. Persepsi responden dalam kategori baik sebanyak 161 orang $(64,9 \%)$. Sebagian kecil persepsi responden dalam kategori buruk sebanyak 87 orang $(35,1 \%)$. responden mempunyai kebiasaan merokok dalam kategori ringan $(<10$ batang/hari) sebanyak 141 orang $(56,9 \%)$. Sebagian kecil responden mempunyai kebiasaan merokok dalam kategori berat ( $>10$ batang/hari) sebanyak 107 orang $(43,1 \%)$. Sebagian besar responden tidak berubah sikapnya sebanyak 158 orang $(63,7 \%)$, sedangkan yang berubah sikapnya sebanyak 90 orang $(36,3 \%)$.

\section{Analisis Bivariat}

Hasil analisis uji bivariat menggunakan fisher exact menunjukkan bahwa variabel yang signifikan karena mempunyai nilai $\mathrm{p}<0,05$ yaitu pendidikan $(\mathrm{p}=0,012)$, pengetahuan $(\mathrm{p}=0,017)$, persepsi $(\mathrm{p}=0,039)$. Sedangkan variabel yang tidak signifikan yaitu umur $(\mathrm{p}=0,623)$, pekerjaan $(\mathrm{p}=0,085)$, dan kebiasaan merokok $(\mathrm{p}=143)$. Selengkapnya dapat dilihat pada tabel berikut.

Tabel 1. Hasil Analisis Bivariat

\begin{tabular}{cccc}
\hline No & Variabel & Nilai p & Keterangan \\
\hline 1. & Umur & 0,623 & Tidak Signifikan \\
2. & Pendidikan & 0,012 & Signifikan \\
3. & Pekerjaan & 0,085 & Tidak Signifikan \\
4. & Pengetahuan & 0,017 & Signifikan \\
5. & Persepsi & 0,039 & Signifikan \\
6. & Kebiasaan Merokok & 0,143 & Tidak Signifikan \\
\hline \multicolumn{3}{c}{ Batas signifikan: 0,05}
\end{tabular}

\section{Analisis Multivariat}

Melakukan pemilihan variabel yang potensial dimasukkan sebagai kandidat model. Dalam pemodelan ini, variabel kandidat yang memiliki nilai signifikan ( $p$-value $)<0,25$ pada uji bivariat sebanyak 5 variabel terdiri dari pendidikan $(p=0,012)$, pekerjaan $(p=0,085)$, pengetahuan $(p=0,017)$, persepsi $(p=0,039)$, dan kebiasaan merokok $(\mathrm{p}=0,143)$, sedangkan variabel umur tidak diikutsertakan dalam pemodelan karena memiliki nilai $\mathrm{p}=0,623>0,05$, selengkapnya dapat dilihat pada tabel berikut ini:

Tabel 2. Seleksi Variabel yang Menjadi Kandidat Model dalam Uji Regresi Logistik Berganda

\begin{tabular}{ccc}
\hline No & Variabel & $\begin{array}{c}\text { Sig. } \\
(\boldsymbol{p} \text {-value })\end{array}$ \\
\hline 1 & Umur & $0,623^{*}$ \\
2 & Pendidikan & 0,012 \\
3 & Pekerjaan & 0,085 \\
4 & Pengetahuan & 0,017 \\
5 & Persepsi & 0,039 \\
$*=$ dikeluarkan dari kandidat model karena memiliki nilai signifikan $(\mathrm{p})>0,25$
\end{tabular}

Selanjutnya dilakukan pengujian dengan regresi logistik berganda secara bersamaan dengan metode forward conditional untuk mengidentifikasi faktor paling berpengaruh terhadap perubahan sikap. Hasil uji regresi logistik berganda menunjukkan bahwa ketiga variabel yang diteliti berpengaruh terhadap perubahan sikap perokok aktif yaitu variabel pendidikan, variabel pengetahuan, dan variabel persepsi. Selengkapnya dapat dilihat pada tabel berikut. 
Tabel 3. Hasil Uji Regresi Logistik Ganda

\begin{tabular}{ccccc}
\hline Variabel & B & Sig. & $\operatorname{Exp}(\mathbf{B})$ & $\mathbf{9 5 \%}$ CI for $\operatorname{Exp}(\mathbf{B})$ \\
\hline Pendidikan & 0,775 & 0,006 & 2,171 & $1,254-3,760$ \\
Pengetahuan & 0,719 & 0,011 & 2,053 & $1,183-3,564$ \\
Persepsi & 0,604 & 0,042 & 1,829 & $1,022-3,271$ \\
Konstanta & $-1,816$ & 0,000 & & \\
\hline
\end{tabular}

Berdasarkan hasil uji regresi logistik berganda tersebut nilai signifikan model secara bersama-sama diperoleh sebesar $\mathrm{p}=0,000<\alpha=0,05$ yang berarti bahwa ketiga variabel yang dijadikan model dalam penelitian ini memiliki pengaruh yang signifikan terhadap perubahan sikap.

Variabel yang paling besar pengaruhnya dalam penelitian ini adalah variabel pendidikan $(\operatorname{Exp}(B)=2,171)$, variabel pengetahuan $(\operatorname{Exp}(B)=2,053)$ dan variabel persepsi $(\operatorname{Exp}(B)=1,829)$. Variabel pendidikan mempunyai nilai $\operatorname{Exp}(\mathrm{B})=2,171$ artinya perokok aktif yang berpendidikan tinggi cenderung berubah sikapnya untuk berhenti merokok 2,1 kali lebih tinggi dibandingkan perokok aktif yang berpendidikan rendah.

Variabel pengetahuan mempunyai nilai $\operatorname{Exp}(B)=2,053$ artinya perokok aktif yang berpengetahuan baik cenderung berubah sikapnya untuk berhenti merokok 2 kali lebih tinggi dibandingkan perokok aktif yang berpengetahuan kurang.

Variabel persepsi mempunyai nilai $\operatorname{Exp}(B)=1,829$ artinya perokok aktif yang mempunyai persepsi baik tentang peringatan kesehatan bergambar cenderung berubah sikapnya untuk berhenti merokok 1,8 kali lebih tinggi dibandingkan perokok aktif yang mempunyai persepsi buruk tentang peringatan kesehatan bergambar pada bungkus rokok.

Model persamaan regresi logistik berganda dari model yang diteliti adalah sebagai berikut:

$$
\begin{aligned}
& \mathrm{p}=\frac{1}{1+\mathrm{e}^{-\left(-1,816+0,77\left\{_{\text {pendidika })}+0,719_{\text {pengetahun })}+0,604_{\text {persepsi) }}\right)\right.}} \\
& \mathrm{p}=57,0 \%
\end{aligned}
$$

Berdasarkan model persamaan tersebut menunjukkan bahwa perokok aktif yang berpendidikan tinggi, berpengetahuan baik, mempunyai persepsi baik tentang iklan gambar peringatan bahaya merokok pada bungkus rokok mempunyai peluang merubah sikapnya sebesar 57,0\%. Hasil tersebut juga menunjukkan bahwa sulitnya untuk merubah sikap perokok aktif untuk menurunkan jumlah rokok yang dikonsumsi atau berubah sikap untuk berhenti merokok. Hal tersebut dikarenakan sebagian perokok aktif sudah banyak yang dalam tahap kecanduan merokok.

Berdasarkan analisis multivariat tersebut juga menunjukkan bahwa variabel yang tidak berpengaruh terhadap perubahan sikap perokok aktif adalah sebagai berikut:

Tabel 4. Hasil Analisis Multivariat Uji Regresi Logistik Ganda Variabel yang Tidak Signifikan

\begin{tabular}{ccc} 
No & Variabel & Sig. $(\boldsymbol{p}$-value $)$ \\
\hline 1 & Pekerjaan & 0,085 \\
2 & Kebiasaan merokok & 0,058 \\
\hline
\end{tabular}

Variabel pekerjaan dan variabel kebiasaan merokok tidak berpengaruh terhadap perubahan sikap perokok aktif karena memiliki nilai $p$ lebih besar dari 0,05 . Variabel pekerjaan memiliki nilai $p$-value $=0,085$, dan variabel kebiasaan merokok mempunyai nilai $p$-value $=0,058$. 


\section{PEMBAHASAN}

\section{Pengaruh Pendidikan terhadap Perubahan Sikap Perokok Aktif}

Pendidikan sejak dulu sampai sekarang merupakan hal terpenting dalam hidup manusia. Pendidikan memberikan kemajuan pemikiran umat manusia, sehingga taraf hidup mereka meningkat. Dalam perkembangannya dari zaman ke zaman pendidikan berubah menjadi suatu sistem. Suatu sistem pendidikan yang tersusun secara sistematis diatur dalam Undang-Undang Republik Indonesia No. 20 tahun 2003 tentang Undang-Undang Sistem Pendidikan Nasional Pasal 11 ayat 1, yang menjelaskan bahwa pendidikan dilaksanakan melalui 3 jalur yaitu pendidikan formal, nonformal, dan informal. Ketiga jalur pendidikan ini satu sama lain saling berkait dan membutuhkan untuk melakukan perubahan sosial yang terjadi di masyarakat kelak. Pendidikan akan mempengaruhi individu dan masyarakat yang pada akhirnya terjadi perubahan sikap dari yang tidak baik menjadi sikap yang baik.

Berdasarkan hasil penelitian menunjukkan bahwa terdapat pengaruh yang signifikan antara pendidikan terhadap perubahan sikap perokok aktif di Lingkungan XXVII Kelurahan Pekan Labuhan Kecamatan Medan Labuhan tahun 2017, $p=0,006<0,05$. Variabel pendidikan mempunyai nilai $\operatorname{Exp}(\mathrm{B})=2,171$ artinya perokok aktif yang berpendidikan tinggi cenderung berubah sikapnya untuk berhenti merokok 2,1 kali lebih tinggi dibandingkan perokok aktif yang berpendidikan rendah.

Penelitian Xu (2015) pada perokok dewasa muda di Chongqing, China menunjukkan perbedaan tingkat pendidikan perokok tentang bahaya merokok. Penelitian tersebut menunjukkan bahwa pria dewasa dengan pendidikan tinggi lebih cenderung memiliki pemahaman merokok yang lebih baik yang membahayakan kesehatan, dan menunjukkan sikap positif terhadap bahaya merokok di antara perokok dewasa muda. Temuan ini selanjutnya mengkonfirmasi bahwa kesadaran akan bahaya kesehatan yang ditimbulkan oleh merokok berkorelasi dengan pendidikan. Studi sebelumnya oleh Margolis (2013) dan Benson (2014) menunjukkan bahwa mereka yang memiliki tingkat pendidikan tinggi dan status sosial ekonomi tinggi lebih cenderung menjadi non-perokok. Penelitian lainnya oleh Giskes (2015) juga menunjukkan bahwa pria berpendidikan tinggi telah menunjukkan tren merokok yang menurun dibandingkan dengan kelompok berpendidikan rendah di banyak negara Eropa. Alasan yang mungkin adalah bahwa orang-orang dengan pendidikan yang lebih baik dapat lebih memahami informasi kesehatan, yang bisa menjadi lebih baik dalam menerjemahkan informasi kesehatan ke dalam tindakan, memiliki lokus kontrol yang lebih tinggi dan mungkin memiliki lebih banyak informasi dan kognisi tentang pentingnya berhenti merokok karena manajemen penyakit.

Pendidikan merupakan suatu proses penyampaian dan pengalihan pengetahuan dari seseorang yang di didik ke arah yang diinginkan, guna perkembangan dan pertumbuhan manusia dalam pendewasaan rohani maupun jasmani, juga dapat berpikir secara ideal dan rasional serta memiliki pengetahuan dan keterampilan untuk memenuhi kebutuhan hidupnya dalam kehidupan bermasyarakat mampu merubah sikap menjadi lebih baik (Slameto, 2013).

Hasil penelitian ini membuktikan bahwa pendidikan responden berpengaruh terhadap perubahan sikap perokok aktif. Hal ini disebabkan karena responden yang berpendidikan tinggi lebih mudah menerima ide-ide baru tentang pentingnya menjaga kesehatan dengan menghindari atau mengurangi kebiasaan merokok dan berupaya untuk merubah sikapnya menjadi lebih baik dengan tidak menjadi perokok lagi. Paparan gambar iklan peringatan bahaya merokok dapat diterjemahkan oleh orang yang berpendidikan tinggi sebagai upaya untuk tetap menjaga 
kesehatan tubuh dan menghindari penyakit yang dapat ditimbulkan oleh rokok seperti penyakit paru-paru, kanker mulut, kanker tenggorokan, impotensi dan lain-lain.

Secara persentase, jumlah responden berpendidikan tinggi yang berubah sikapnya setelah terpapar gambar iklan rokok juga lebih tinggi dibandingkan dengan responden yang berpendidikan rendah yaitu $43,6 \%$ berbanding $2,8 \%$. Hal tersebut menunjukkan bahwa tingkat pendidikan seseorang berpotensi untuk merubah sikap dan perilakunya yang tidak baik tentang rokok dibandingkan responden yang berpendidikan rendah yang tidak mau berubah sikap walaupun sudah terpapar atau melihat gambar iklan peringatan bahaya merokok karena menganggap merokok tidak terlalu masalah dengan kesehatannya.

\section{Pengaruh Pengetahuan terhadap Perubahan Sikap Perokok Aktif}

Pengetahuan merupakan hasil tahu dan ini terjadi setelah orang melakukan penginderaan terhadap suatu obyek tertentu. Penginderaan terjadi melalui panca indera manusia yaitu : indera penglihatan, pendengaran, penciuman, rasa dan raba. Sebagian besar pengetahuan manusia diperoleh dari penglihatan. Setelah orang tersebut tahu maka ia akan dapat menentukan sikap.

Berdasarkan hasil penelitian menunjukkan bahwa terdapat pengaruh yang signifikan antara pengetahuan terhadap perubahan sikap perokok aktif di Lingkungan XXVII Kelurahan Pekan Labuhan Kecamatan Medan Labuhan tahun 2017, $\mathrm{p}=0,011<0,05$. Variabel pengetahuan mempunyai nilai $\operatorname{Exp}(B)=2,053$ artinya perokok aktif yang berpengetahuan baik cenderung berubah sikapnya untuk berhenti merokok 2 kali lebih tinggi dibandingkan perokok aktif yang berpengetahuan kurang.

Penelitian Xu (2015) pada perokok dewasa muda di Chongqing, China menunjukkan perbedaan pengetahuan perokok tentang bahaya merokok. Perbedaan merokok dalam skor rata-rata kognisi bahwa Merokok menyebabkan penyakit paru-paru $(\mathrm{p}=0,008)$, merokok menyebabkan kanker mulut ( $\mathrm{p}<0,0001)$, merokok menyebabkan penyakit jantung $(\mathrm{p}=0,017)$, merokok menyebabkan stroke $(\mathrm{p}=0,008)$, dan merokok menyebabkan impotensi $(\mathrm{p}=0,021)$.

Penelitian Ganley (2013) yang meneliti populasi berusia 30 tahun atau lebih muda dengan menggunakan instrumen dari Survei Tembakau online, didistribusikan melalui email, Facebook, dan media sosial lainnya. Hasil menunjukkan norma dan sikap subjektif dapat memprediksi merokok namun pengetahuan bukanlah prediktor. Lebih dari $70 \%$ perokok mencoba rokok pertama mereka sebelum usia 18 tahun. Sebagian besar alasan merokok yang dilaporkan adalah konsumsi alkohol, merokok dengan teman di lingkungan sosial, menghilangkan stres, dan relaksasi. Tujuh puluh lima persen perokok setuju bahwa merokok itu kecanduan dan pengetahuan tinggi mengenai bahaya merokok. Kurang dari $50 \%$ perokok berencana untuk berhenti dalam tahun depan.

Pengetahuan tentang bahaya merokok adalah elemen kunci untuk perubahan sikap, pencegahan dan menghentikan kebiasaan merokok. Menurut model latihan pengetahuan-sikap, perubahan dalam perilaku melibatkan perolehan pengetahuan yang relevan, perubahan sikap yang terkait dan, akhirnya, mengubah praktik. Penelitian Li (2011) di China hanya menemukan hubungan yang lemah antara pengetahuan tentang merokok dan perilaku merokok yang sebenarnya. Studi dari negara-negara Barat yaitu Finney (2013) dan Nobil (2010) melaporkan bahwa mantan perokok dua kali lebih mungkin perokok saat ini menyadari bahaya merokok, namun studi serupa oleh Han (2011) di China menemukan hubungan yang jauh lebih lemah (atau tidak ada) antara status merokok dan pengetahuan. dari risiko kesehatan merokok. 
Secara teori perubahan sikap dan perilaku memiliki tahap proses perubahan dari pengetahuan. Beberapa penelitian telah membuktikan hal ini, namun ada pula yang sebaliknya seperti seseorang telah berperilaku positif meskipun pengetahuan dan sikapnya negatif (Notoatmodjo, 2015). Pada penelitian Azwar (2014) menyatakan faktor pengetahuan berhubungan dengan perubahan sikap dan tindakan merokok. Demikian juga pada penelitian Noor (2015) menyatakan ada hubungan antara tingkat pengetahuan tentang bahaya rokok dengan perubahan sikap dan perilaku merokok.

Penelitian ini menunjukkan bahwa lebih banyak perokok aktif yang mempunyai pengetahuan baik tentang bahaya rokok dan iklan peringatan bergambar pada bungkus rokok tetapi jika dilihat dari keinginan untuk berubah masih tinggi jumlah responden yang tidak berubah $(56,9 \%)$ dibandingkan dengan jumlah responden yang tidak berubah $(43,1 \%)$. Hal ini disebabkan peran pemerintah untuk mempromosikan iklan peringatan bahaya merokok pada bungkus rokok dan iklan di media massa lainnya membuat banyak orang yang tahu tentang dampak rokok terhadap kesehatan. Tetapi keinginan untuk berubah masih berat karena merokok sudah menjadi kebutuhan hidup sehari-hari seperti makan bahkan untuk beberapa orang sudah menjadi candu sehingga konsumsi rokok lebih banyak dibandingkan dengan makannya. Demikian juga jika dikaitkan dengan biaya pengeluaran untuk rokok sebagian responden lebih besar dibandingkan untuk biaya pengeluaran untuk makannya sehari-hari terutama pada perokok berat yang dapat menghabiskan rokok lebih dari 2 atau 3 bungkus.

Pengetahuan yang baik juga belum tentu akan merubah sikap mereka untuk berhenti merokok. Hasil penelitian ini menunjukkan bahwa walaupun perokok aktif tersebut memiliki pengetahuan yang baik tentang rokok dan bahaya rokok tetapi sebagian dari mereka tetap tidak mau berubah sikapnya. Efek candu dan rasa nikmat rokok mengalahkan apa yang mereka pahami bahwa merokok merusak kesehatan tubuh. Efek rokok yang tidak serta merta terjadi secara langsung pada perokok juga menyebabkan mereka tidak takut terhadap bahaya rokok, karena apa yang mereka lihat bahwa banyak juga orang yang merokok tetapi umurnya tetap panjang, sampai tua masih merokok.

\section{Pengaruh Persepsi terhadap Perubahan Sikap Perokok Aktif}

Berdasarkan hasil penelitian menunjukkan bahwa terdapat pengaruh yang signifikan antara persepsi terhadap perubahan sikap perokok aktif di Lingkungan XXVII Kelurahan Pekan Labuhan Kecamatan Medan Labuhan tahun 2017, $p=0,042<0,05$. Variabel persepsi mempunyai nilai $\operatorname{Exp}(B)=1,829$ artinya perokok aktif yang mempunyai persepsi baik tentang peringatan kesehatan bergambar cenderung berubah sikapnya untuk berhenti merokok 1,8 kali lebih tinggi dibandingkan perokok aktif yang mempunyai persepsi buruk tentang peringatan kesehatan bergambar.

Kesimpulan penelitian Fuad (2014) mengenai persepsi masyarakat terhadap visual pada "disclaimer" mengenai peringatan bahaya merokok pada media iklan rokok cetak dan elektronik menunjukkan bahwa seberapa seram, menakutkan, menjijikkan apapun gambar yang tampak. Itu semua tidak akan membuat para perokok berhenti untuk merokok. Bahkan untuk para calon perokokpun tidak akan bisa untuk dilarang mencoba bagaimana rasanya merokok. Tidak merokok ataupun berhenti merokok itu adalah datangnya dari diri sendiri. Pemerintah hanya dapat menghimbau, memperingati, memberitahu bahaya merokok

Hasil penelitian yang dilakukan oleh Calvin (2014) di Kelurahan Sei Rengas II, Kecamatan Medan Area menunjukkan bahwa terdapat pengaruh pesan peringatan kesehatan pada bungkus 
rokok terhadap kesadaran perokok. Beberapa alasan yang biasa diungkapkan oleh perokok untuk mempertahankan kebiasaan buruknya adalah ingin dianggap jantan, mengikuti gaya hidup, mengurangi stress, sudah kecanduan dan sebagai sarana refreshing.

Penelitian Blanton (2014) yang meneliti partisipan secara online sebanyak 1.169 warga Amerika berumur 18-24 tahun mendapatkan hasil bahwa peringatan grafis pada bungkus rokok dapat mengurangi minat merokok di kalangan perokok, sebuah temuan yang mendukung hipotesis perubahan adaptif. Peringatan grafis yang menargetkan perokok sesekali mungkin lebih efektif dalam mengubah sikap dan mengurangi merokok pada orang dewasa muda.

Penelitian Heydari (2011) di Iran bahwa persepsi responden dari segi kualitas gambar, 61,6\% tidak memiliki pendapat, dan $28,7 \%$ menyatakan bahwa gambar memiliki kualitas yang buruk. Tidak ada perbedaan yang signifikan yang diamati antara merek Iran atau asing dalam hal tingkat merokok setelah menerapkan label peringatan bergambar. Heydari awalnya percaya bahwa tingkat merokok akan menurun setelah menerapkan label peringatan kesehatan bergambar pada bungkus rokok. Namun, hal itu tidak terjadi. Selain itu, mengadopsi label ini tidak memiliki efek signifikan pada perokok yang mengubah merek favorit mereka dari merek Iran ke merek asing atau sebaliknya. Untuk itu, jenis dan kualitas gambar ada bungkus rokok memerlukan revisi dan koreksi utama.

Masyarakat saat ini kini telah terinternalisasi berbagai iklan rokok yang "dikemas" melalui pencitraan bahwa rokok adalah "jantan", "lelaki sejati", hingga "persahabatan", muatan nilai yang berbanding terbalik dengan produk rokok akan menciptakan sikap kontradiktif (berlawanan), padahal sesungguhnya rokok salah satu produk adiktif, yang dalam proses pemasarananya harus melalui pengawasan ketat dan menyeluruh (Zulkarnain, 2015).

Persepsi dan pikiran seseorang terbentuk karena pengalamannya berdasarkan asosiasi antara stimuli asal dan stimuli yang terkondisikan. Namun, pendapat tersebut ada kelemahannya, terutama pengalaman yang bersifat pribadi serta pengertian dan kecerdasan seseorang yang terbatas. Selain itu, ketidakmampuan untuk benar-benar menyadari persepsi yang dimiliki akan mengganggu interpretasi kenyataan yang sebenarnya. Perbedaan persepsi tersebut terjadi karena perbedaan kepentingan. Kepentingan perokok yang mendapatkan kenikmatan berbeda dengan kepentingan bukan perokok untuk kesehatan dan penampilan. Sehingga perbedaan antara responden yang berpendidikan rendah dengan yang berpendidikan tinggi, responden berpengetahuan baik dan berpengetahuan kurang, memiliki persepsi baik dan persepsi buruk terhadap gambar peringatan bahaya merokok menjadi hal yang menentukan apakah sikap mereka akan berubah atau tidak.

Kecenderungan perokok aktif akan berubah sikapnya dengan tidak menjadi perokok lagi dapat dibuktikan dari hasil penelitian ini bahwa dengan persepsi yang baik tentang gambar iklan peringatan bahaya merokok pada bungkus rokok akan menjadi pertimbangan perokok aktif untuk merubah sikap dan menghentikan kebiasaan merokok, karena jika kebiasaan tersebut diteruskan akan berdampak terhadap terjadinya gangguan kesehatan seperti yang ditampilkan pada iklan peringatan bahaya merokok pada bungkus rokok tersebut.

Dalam penelitian ini juga ditemukan bahwa sebanyak 95 orang $(59,0 \%)$ yang mempunyai persepsi baik tetapi tidak mau berubah sikapnya setelah melihat gambar iklan peringatan bahaya merokok. Hal ini disebabkan mereka beranggapan selama ini menjadi perokok tidak pernah mengalami seperti yang digambarkan pada bungkus rokok tersebut sehingga walaupun 
mereka mempunyai persepsi yang baik tentang iklan peringatan bahaya merokok pada bungkus rokok tetapi tidak mempengaruhi mereka untuk merubah sikapnya. Anggapan bahwa banyak orang merokok di sekitar mereka juga tidak ada yang mengalami seperti pada bungkus rokok tersebut sehingga mereka berpandangan bahwa ada gambar iklan peringatan bahaya merokok maupun tidak ada gambar iklan peringatan bahaya merokok tidak mempengaruhi kesehatan mereka atau sama saja.

Pandangan tersebut muncul karena selama ini para perokok tetap baik-baik saja, kalaupun ada perokok yang menderita batuk karena orang yang tidak merokok pun mengalami batuk, ada perokok yang menderita sakit paru-paru menurut mereka bukan karena hanya merokok tetapi faktor kondisi tubuhnya yang memang tidak kuat, dan mereka yang bekerja dengan tingkat polusi tinggi seperti tukang becak, supir, dan lain-lain. Jadi, persepsi mereka yang demikian tersebut bisa juga disebabkan karena pengalaman selama ini mereka baik-baik saja sehingga mereka merasa tidak perlu menghentikan kebiasaan merokok tersebut.

Menurut peneliti, perokok aktif melihat gambar iklan peringatan bahaya merokok pada bungkus rokok setiap hari akan menjadi biasa dan tidak menimbulkan efek rasa takut, mungkin pada awal-awalnya saja mereka akan merasa takut dengan tampilan gambar iklan bahaya rokok pada bungkus rokok tersebut. Gambar yang dilihat secara berulang-ulang dan pada kenyataannya tidak menimbulkan seperti yang digambarkan tersebut pada diri perokok aktif tersebut membuat mereka menjadi kebal terhadap informasi tersebut dan tidak lagi mempedulikan gambar peringatan bahaya rokok yang ada pada bungkus rokok tersebut.

\section{KESIMPULAN}

Kesimpulan penelitian ini bahwa pendidikan, pengetahuan, dan persepsi tentang gambaran iklan peringatan bahaya merokok berpengaruh terhadap perubahan sikap perokok aktif. Sedangkan umur, pekerjaan, dan kebiasaan merokok tidak mempengaruhi perubahan sikap perokok aktif di Lingkungan XXVII Kelurahan Pekan Labuhan. Variabel yang paling besar pengaruhnya terhadap perubahan sikap perokok aktif adalah variabel pendidikan. Perokok aktif yang berpendidikan tinggi, berpengetahuan baik, mempunyai persepsi baik tentang iklan gambar peringatan bahaya merokok pada bungkus rokok mempunyai peluang merubah sikapnya sebesar $57,0 \%$. Hal tersebut menunjukkan sulitnya untuk merubah sikap merokok yang sudah menjadi kebiasaan.

\section{DAFTAR PUSTAKA}

Ajzen. I. 1991. The Theory of Planned Behaviour. In: Organizational Behaviour and Human Decision Process. Amherst, MA: Elsevier

Aula, L.E. 2014. Stop Merokok. Cetakan Pertama. Yogyakarta: Garailmu.

Azwar, E. 2014. Determinan Perilaku merokok pada mahasiswa Fakultas Kesehatan Masyarakat Universitas Muhammadiyah Aceh Provinsi Naggroe Aceh Darussalam. Thesis. Magister Ilmu Kesehatan Universitas Gadjah Mada.

Baron, R.A., \& Byrne. D. 2012. Psikologi Sosial. Cetakan Pertama. Edisi 2. Jakarta: Erlangga.

Benson F.E., Stronks K., Willemsen M.C., Bogaerts N.M.M., Nierkens V. 2014. Wanting to attend isn't just wanting to quit: Why some disadvantaged smokers regularly attend smoking cessation behavioral therapy while others do not: A qualitative study. BMC Public Health.

Blanton, H, Snyder, L.B, Strauts, E, Larson, J.G. 2014. Effect of Graphic Cigarette Warnings on Smoking Intentions in Young Adults. PLoS One. 2014; 9(5).

Calvin. 2014. Pengaruh Pesan Peringatan Kesehatan Terhadap Kesadaran Perokok (Studi Korelasional Pengaruh Pesan Peringatan Kesehatan Pada Bungkus Rokok Terhadap Kesadaran Perokok di 
Kelurahan Sei Rengas II Kecamatan Medan Area Kota Medan). Medan : Fakultas Ilmu Sosial Dan Ilmu Politik Departemen Ilmu Komunikasi Universitas Sumatera Utara.

Choi, K. 2013. Minnesota smokers' perceived helpfulness of 2009 federal tobacco tax increase in assisting smoking cessation: a prospective cohort study. BMC Public Health, 13, 965.

Faisal, B. 2013. Mencegah Serangan Jantung. Cetakan Pertama. Jakarta : Gramedia Pustaka Utama.

Finney, S., Rutten L.J, Augustson E.M, Moser R.P. 2013. Smoking knowledge and behavior in the United States: sociodemographic, smoking status, and geographic patterns. Nicotine Tob Res 2008;10:1559-70.

Fuad, A. 2014. Dampak Persepsi Masyarakat Terhadap Visual Pada "Disclaimer" Mengenai Peringatan Bahaya Merokok Pada Media Iklan Rokok Cetak Dan Elektronik. Inosains. Volume 9 Nomor 2, Agustus 2014.

Ganley, B.J. 2013. The smoking attitudes, knowledge, intent, and behaviors of adolescents and young adults: Implications for nursing practice. Journal of Nursing Education and Practice, January 2013, Vol. 3, No. 1.

Giskes, K., Kunst A.E., Benach J., Borrell C., Costa G., Dahl E., Dalstra J.A., Federico B., Helmert U., Judge K. 2015. Trends in smoking behaviour between 1985 and 2000 in nine European countries by education. J. Epidemiol. Community Health. 2015;59:395-401.

Han, M.Y, Chen WQ, Chen X. 2011. Do smoking knowledge, attitudes and behaviors change with years of schooling? A comparison of medical with non-medical students in China. J Community Health 2011;36:966-74.

Heydari. G.R. 2011. The Impacts of Cigarette Packaging Pictorial Warning Labels on Smokers in the City of Tehran. Tanaffos. 2011; 10(1): 40-47.

Heikkinen, S., Huttunen, R., 2010. Smoking and the outcome of infection. Journal of Internal Medicine, $258-269$.

Kemenkes RI. 2014. Dampak Rokok Terhadap Kesehatan dan Ekonomi. Jakarta: Kementerian Kesehatan Republik Indonesia.

Kemenkes RI, 2015. Hari Tanpa Tembakau Sedunia. Jakarta: Infodatin Pusat Data dan Informasi Kementerian Kesehatan Republik Indonesia.

Li, Q., Hsia J., Yang G. 2010. Prevalence of smoking in China in 2010. NEJM 2011; 364:2469-70

Lousia, M., Sadikin, Z.D. 2013. Program Berhenti merokok. Majalah Kedokteran Indonesia. Hal. 131137.

Margolis, R. 2013. Educational differences in healthy behavior changes and adherence among middleaged Americans. J. Health Soc. Behav. 2013;54:353-368.

Martiany, D. 2016. Kendali Jumlah Perokok Untuk Melindungi Kesehatan Perempuan. Majalah Info Singkat Kesejahteraan. Vol. VIII, No. 16/II/P3DI/Agustus/2016.

Morissan, Andy C.W., Farid H.U. 2015. Teori Komunikasi Massa. Jakarta: Ghalia Indonesia.

Noor, F. 2015. Faktor-Faktor Yang Berpengaruh Terhadap Praktik Merokok Pada Pelajar Sekolah Menengah Pertama di Kabupaten Kudus. Thesis. Magister Promosi Kesehatan UNDIP.

Notoatmodjo, S. 2015. Promosi Kesehatan dan Ilmu Perilaku. Cetakan Pertama. Jakarta: Rineka Cipta.

Peraturan Pemerintah Nomor 109 Tahun 2012 tentang Pengamanan Bahan yang Mengandung Zat Adiktif Berupa Produk Tembakau Bagi Kesehatan.

Peraturan Menteri Kesehatan No. 28 Tahun 2013 tentang Pencantuman Peringatan Kesehatan dan Informasi Kesehatan pada Kemasan Produk Tembakau Berbentuk Gambar dan Tulisan.

Undang-Undang Republik Indonesia No. 20 tahun 2003 tentang Undang-Undang Sistem Pendidikan Nasional.

Xu, X., Liu L., Sharma, M., and Zhao, Y. 2015. Smoking-Related Knowledge, Attitudes, Behaviors, Smoking Cessation Idea and Education Level among Young Adult Male Smokers in Chongqing, China. 
PENGARUH KARAKTERISTIK DAN PERSEPSI INDIVIDU TENTANG PERINGATAN BAHAYA MEROKOK PADA BUNGKUS ROKOK

TERHADAP PERUBAHAN SIKAP PEROKOK AKTIF DI LINGKUNGAN

XXVII KELURAHAN PEKAN LABUHAN KECAMATAN MEDAN LABUHAN
Eva Nirwana Natalia Hutabarat, et.al. 